FACTA UNIVERSITATIS

Series: Teaching, Learning and Teacher Education Vol. 1, $\mathrm{N}^{\mathrm{o}} 2,2017$, pp. 87 - 100

https://doi.org/10.22190/FUTLTE1702087M

Original research paper

\title{
STUDENT'S ACHIEVEMENT AND REQUIREMENTS OF THE EDUCATIONAL OBJECTIVES IN THE MATHEMATICS CURRICULUM IN PRIMARY SCHOOL
}

\author{
UDC $371.3:: 51$
}

\section{Nela Malinović-Jovanović}

Pedagogical Faculty in Vranje, University of Niš

\begin{abstract}
The paper presents the results of research on the achievements of the third and fourth grade of primary school students in relation to the requirements of the objectives and learning outcomes given in the Mathematics Curriculum for Primary School. In order to examine the achievements of students, i.e. the level of achievement of objectives about natural numbers, a taxonomic model of operationalization of the goal and objectives of teaching mathematics was used. The survey was conducted on a sample of 341 students of the third and 315 students of the fourth grade in three Primary Schools in the population of students of the third and fourth grades of primary schools in Pčinja District in Serbia. A descriptive method was used in all its variants: analytical, comparative and classification, and in accordance with that the analysis technique and testing of the content was applied. As an instrument, criterion-referenced tests were created for the purpose of research, which determined what and to what level of knowledge in terms of quality were the students acquired from what was planned. The obtained results indicate that the students did not achieve the most of objectives given in the Mathematics Curriculum, considering the quality of knowledge they include, which was determined on the basis of an analysis of the requirements of objectives and learning outcomes and in accordance with categories of knowledge of given taxonomic model. The results of this theoretical-empirical research can contribute to changes in the approach to teaching contents: in changing and innovating the mathematics curriculum, in presenting the content of the program; the operationalization of the goal and objectives; the quality of evaluating and assessing student achievement; validity and quality of tests of knowledge and skills, and others.
\end{abstract}

Key words: educational objectives, taxonomy, student's achievements, level of achievements of educational objectives, Mathematics Curriculum

Received December 30, 2017/Accepted January 10, 2018

Corresponding author: Nela Malinović-Jovanović

Pedagogical Faculty inVranje, University of Niš, Partizanska 14, 17500 Vranje, Serbia

Phone: +381 17 431-960•E-mail: nelamj@ucfak.ni.ac.rs 


\section{INTRODUCTION}

Along with the creation of the mathematics curriculum for the first four grades of primary school, the goals and objectives of teaching are designed with the intention to be achieved in the education and training process. "They are the starting point, but also the result of every educational process. The educational process begins with a certain intent, and ends with a testing of how much this intention has been achieved" (Bognar, Matijević, 2002, 158).

The goals of education at the same time determine the results that are to be achieved in the overall educational work and serve as a direction for curriculum development. They represent the end of the educational process and anticipate future results. Within goals, general and operational objectives, as well as program contents, there is a need for a correlation, which together makes a coherent whole. From didactic-methodical point of view, that whole should be a system of goals and objectives, in other words, such a sequence of objectives that will ensure continuity, integrity and operability of teaching. On the other hand, it is important that in the process of acquiring knowledge there is a hierarchical order that coincides with a hierarchically organized series of psychological processes (i.e. arranged in such a way that it starts from the simplest to the most complex ones). Classification of educational goals and tasks into categories, hierarchically distributed, so that each of the following ones contains the requirements of those who precede it in the sequence, which represents one pedagogical-logical-psychological system, represents the taxonomy of goals and objectives. "The Taxonomy of Educational Objectives is a scheme for classifying educational goals, objectives, and, most recently, standards. It provides an organizational structure that gives a commonly understood meaning to objectives classified in one of its categories, thereby enhancing communication" (Krathwohl, 2002, 218).

One of the creators of the taxonomy of objectives is American psychologist B. Bloom (Bloom, 1981, Bloom, et al., 1956), whose taxonomy is based on a cognitive, affective and psychomotor field. However, no modern theory of teaching and learning does not justify Blum's separation of teaching activities into these mentioned fields with regard to their mutual connection, and therefore the taxonomy is mainly used in teaching practice in the cognitive field.

Many of the supporters of behavioral theories of learning insisted on the strict hierarchy of the educational objectives that were given in taxonomies of Tyler (1949), Mager (Mager, 1997), Anderson and Krathwohl (Anderson, Krathwohl, et al., 2001) that originated on base of Bloom's taxonomy as A Revision of Bloom's Taxonomy of Educational Objectives.

Alike Bloom's, Gagne's (Gagne, 1992) taxonomy is based on the hierarchical classification of educational objectives in the cognitive domain, and in many European countries it is increasingly used in the area of testing and assessing students' knowledge.

"Critics of the Bloom's taxonomy have questioned whether human cognition can be divided into distinct categories, particularly sequential or hierarchical categories. Others embrace the utility of the classification system, while still recognizing that it does not and cannot represent human thought or learning in all their complexity and sophistication. Most criticism is focused less on the system itself and more on the ways in which educators interpret and use the taxonomy" (The Glossary of Education Reform, 2014).

Since the Taxonomy of Educational Objectives was published, a "number of attempts have been made to revise Bloom's taxonomy so that incorporates modern advances in the understanding of human thought and the structure of knowledge. As a practical tool for 
educators, Bloom's taxonomy is superior to all other attempts to date" (Marzano, Kendall, 2007, xi) "While still widely used, Bloom's taxonomy is gradually being supplemented and may perhaps even supplanted one day by new insights into the workings of human thought and learning made possible by advances in brain imaging and cognitive science. Still, it is likely, given its logical simplicity and utility that Bloom's taxonomy will continue to be widely used by educators" (The Glossary of Education Reform, 2014).

The advantage is also the fact that in the TIMSS research conducted every four years in more than 60 participating countries, "a support found in the division of knowledge according to Bloom's taxonomy" (Milanović-Nahod, 2005, 347). The concept of this research is contained in the development of a curriculum model that is defined as: "The major organizing concept in considering how educational opportunities are provided to students, and the factors that influence how students use these opportunities" (Mullis, et al., 2007, 4).

By application of taxonomy in defining educational goals allows: more efficient and quality individualization of the learning process in terms of creating quality alternative learning models for all categories of students, starting from those who lag behind in learning, to those who are the most creative and the most talented; "Creating criterionreferenced tests determine what the students have achieved and to what level in relation to the target goals in the program" (Vučić, 1979, 27); defining the criteria and standards of assessment that are reflected in the description of knowledge, skills and habits that student's should achieve at a certain level of education.

The significance of the mentioned taxonomies, among other things, is also reflected in the fact that they help formulate such tasks and questions that will be hierarchically arranged by categories, whereby the complexity of all categories or the levels of knowledge in terms of quality, the process of thinking and solving the problem, must be taken into account. If one starts from the lowest categories of knowledge (recall, recognition, reproduction) to the highest (comprehension, application, problem solving, creativity), it is possible for any of the categories to compile a number of questions and tasks that would be indicators and measure knowledge and behavior which is characteristic for each of the categories, which would, among other things, enable the setting of criteria and standards of objective assessment.

The problem is reflected in determining a clear boundary between categories of knowledge and abilities, i.e. determining educational levels, for which there is no ideal methodology in the world. This is supported by the fact that the TIMSS researchers in "each cycle change both the tasks and determinants of knowledge, i.e. cognitive levels" (Milanović-Nahod, 2005, 347). Accordingly, there is a problem of formulating tasks in tests, which indicators would measure the appropriate quality, the question of validity of tasks, i.e. whether the tasks measure the quality of knowledge to be measured (MilanovićNahod, 2005, 349). How to construct a model suitable for monitoring, assessment and evaluating of the achieved goals and objectives of each student, is one of the questions that still does not have a precise answer.

Therefore, the actuality of the problem of researching the level of achievements of the goal and the objectives in accordance of the taxonomic model arises from the fact that modern teaching is based on the defined educational objectives. This allows for adequate planning of processes and procedures in teaching, the development of a taxonomic model of goals and objectives and determining the level of its realization. In examining the level of achievement of the objectives of mathematics teaching it was started from the operationalization of the objectives of initial mathematics teaching for the third and fourth grades of the primary school and the taxonomic model constructed for the purpose of research, as an indicator of the level of their realization. 


\section{OPERATIONALIZATION OF EDUCATIONAL OBJECTIVES IN THE MATHEMATICS CURRICULUM IN PRIMARY SCHOOL}

The operationalization of the educational goal and objectives, for each individual subject, ensures objectives and educational results that "determine what the students need to know and understand in order to be able to say that the goals are achieved. Thus, the demands placed in the goal and objectives are concretized through clearly distinguished knowledge and skills, by level of achievement" (Malinović-Jovanović \& Stojanović, 2015, 358). In our case, the operationalization referred to the determination of educational objectives, learning outcomes and contents that are being studied in the third and fourth grade in the primary school and are related to the field of natural numbers, and on the basis of that, determining which quality of knowledge is expected for students to have after processed contents. The goal, objectives and educational outcomes are given in the Mathematics Curriculum for the third and fourth grade of the primary school (The Curriculum for Third Grade of Primary Education, 2005, 2006, 2008 and 2010; The Curriculum for Fourth Grade of Primary Education, 2006, 2008), so in order to determine the expected level of students' knowledge, its analysis was done from the following aspects: the compatibility of objectives, outcomes and the contents that relate to them and the classification of objectives according to the taxonomic model of the operationalization of the goals and objectives of teaching (Bogdanović \& Malinović-Jovanović, 2009, 620).

Here is a list of the objectives for the third and fourth grade of primary school.

Third grade. Students should be taught to:

3.1. acquire reading, writing and comparing natural numbers up to 1000 ;

3.2. successfully perform all four operations up to 1000 ;

3.3. use the patterns of the operations for more rational calculation; they can read and write by using the letters for all four operations;

3.4. recognize the dependence of the results of the patterns of the operation;

3.5. know how to calculate the value of a numeric expression with a maximum of three operations; they know how to determine the value of the expression with letters from the given letter value;

3.6. know how to solve simpler equations in a set of numbers up to 1000 ;

3.7. successfully solve textual tasks.

Fourth grade. Students should be taught to:

4.1. successfully acquire the reading and writing of natural numbers in a decimal numeral system;

4.2. know a set of natural numbers;

4.3. learn to integrate natural numbers into the points of the numerical halflength;

4.4. understand the application of operations in the set $N$, i.e. $N_{0}$;

4.5. know to read and write by letters the basic patterns of operations; apply the familiar patterns of operations during the transformation of terms and in the case of calculations;

4.6. recognize and notice the dependence between the results and the components of the operation (on examples);

4.7. know how to read, compose, and calculate the value of expressions with multiple operations,

4.8. know how to solve simpler equations and inequalities in a set of natural numbers;

4.9. successfully solve (using terms and equations) the tasks given in the textual form. 
Based on the analysis that was performed, the following was concluded: based on the formulated objectives, the contents to which they relate cannot be precisely determined; the outcomes are not aligned with the objectives, and the objectives are not aligned with the content given in third and fourth grade; the way the program is implemented, generally, includes the essential characteristics of the curriculum, as well as the way of realization, which removes somewhat the above mentioned deficiencies. (MalinovićJovanović, 2010; Malinović-Jovanović \& Stojanović, 2015).

Also, since the taxonomy does not consist an integral part of the curriculum, based on the requirements of objectives and outcomes, it is not possible to state with certainty to which category of knowledge they belong, because based on the used formulations in them (acquiring, successfully performing, perceiving ...) cannot precisely determine the level of knowledge that corresponds them.

Based on the explanation of the way that program content is realized, the objectives can be classified with certain accuracy into the appropriate categories of the taxonomic model. The classification of the objectives in third and fourth grade, where each educational objective is classified into the highest category which corresponds to a particular task, is given in Table 1.

Table 1 Classification of objectives in third and fourth grade

\begin{tabular}{lcc}
\hline Categories of the & \multicolumn{2}{c}{ Objectives } \\
\cline { 2 - 3 } taxonomy model & Third grade & Fourth grade \\
\hline Recognition & & \\
Reproduction & 3.4. & 4.2. \\
Comprehension & $3.5 . ; 3.6$. & $4.3 . ; 4.4$. \\
Operationalization & $3.3 . ; 3.1 . ; 3.2 . ; 3.7$. & $4.1 . ; 4.5 . ; 4.6 . ; 4.7 . ; 4.8 . ; 4.9$. \\
Creative problem solving & & \\
\hline
\end{tabular}

Based on the Table 1, it can be concluded that most of the requirements are at the level of productive knowledge, the knowledge with understanding is required, while the smaller part is on the level of reproductive knowledge. However, the devastating fact is that none of the requirements given in the objectives does not include knowledge at the level of problem solving. Even the requirement relating to the solution of textual tasks assumes the highest category of application.

On the other hand, the Regulation of Student Assessment in Primary Education provides that a student who meets "the most of the requirements from an advanced level of specific standards of achievement, with a very high degree of engagement, gets an excellent grade (5)" (The Regulations of the Assessment of Students in Primary Education, 2009, 2011 and 2013), while the educational standards for the first cycle of education in the field of the natural numbers and operations provides that the student at an advanced level, "can use the properties of the natural numbers in solving problem's tasks" and that "can solve complex problem's tasks given in the text form" (The Regulation of the Educational Standards for the End of the first cycle of the compulsory Education for school subjects Serbian language, Mathematics and Nature and Society, 2011); which implies knowledge at the level of creative problem solving, so it is not very clear why the requirements given in the curriculum do not imply to this.

Considering to the performed classification of the objectives, we were interested in which extent students can achieve its requirements in relation to the knowledge categories they 
imply, and accordingly, the goal of the research was to determine the level of achievement of the objectives of teaching natural numbers in the third and fourth grade in Primary School in relation to their classifications in the Curriculum of Mathematics.

\section{METHODOLOGICAL FRAMEWORK OF RESEARCH}

The survey was conducted on a sample of 341 students of the third and 315 students of the fourth grade in three Primary Schools in Pčinja District in Serbia. The population consisted of 3623 students of the third and 3548 students of the fourth grade, so the sample significantly exceeded the selecting rate of 0.05 (i.e. $5 \%$ ).

The selection of methods, techniques and instruments used in the research was carried out regarding to the nature of the problem. A descriptive method was used in all its variants: analytical, comparative and classificational, and in accordance with the analysis technique and testing of the content was applied. The analysis technique of content was used to provide information on the descriptions of the level of knowledge in terms of quality that provide the basis for making conclusions about the students' achievements. Also, the logical analysis examined the substantive validity of the tasks given in the tests to determine whether the tasks included all the requirements given to the corresponding objectives and whether they are in accordance with the levels of knowledge to be measured and which are determined by the taxonomic model.

As an instrument, criterion-referenced tests were created for the purpose of research, which determined "what and to what level of knowledge in terms of quality were the students acquired from what was planned. The precondition for creating this type of tests is: preformulated educational goals and objectives of the initial teaching of mathematics and the category of the taxonomic model" (Vučić 1997, 28). For each goal, tasks were created to examine whether the goal was achieved or not, or whether the objectives were achieved within the goal. What students need to know after the content processing, is determined by the requirements of the objectives given in the Primary Mathematics Curriculum, and Table 1 lists their classification according to the categories of knowledge of the taxonomic model.

To which the level of quality, the students achieved the given objectives was determined by the constructed taxonomic model (Bogdanović, Malinović-Jovanović, 2009, 620). The taxonomic model is aligned with Bloom's taxonomy in the cognitive domain (Bloom, 1981) and the categories of knowledge given in the Mathematics Curriculum for Primary School and contains five categories of knowledge: recognition, reproduction, comprehension, operationalization and creative problem solving. The level of accomplishment of the objectives was carried out with respect to each of the mentioned categories. Consequently, five tests have been created: the recognition test, the reproduction test, the comprehension test and the operational and creative problem solving test. The tests included tasks such as: truefalse, multiple-choice, matching, completing, detecting relationships among given elements, open ended (which require a short answer to the given question) and constructed-response questions (with a more complex answer). The true-false, multiple-choice, matching, completing, detecting relationships among given elements questions were used in recognition test. The completing questions were used in the reproduction tests but only in cases in which students should make conclusion on the base of data in given tasks by completing appropriate statements. In all other tests, only constructed-response questions were used adapted to the category of knowledge they needed to measure, since that kind of questions are "particularly well-suited for assessing aspects of knowledge and skills that require students to explain 
phenomena or interpret data based on their background knowledge and experience" (Mullis, et al., 2007, 103).

The number of tasks in each test depended on the requirements that are covered by the given objectives and each task in the test was scored with as maximum points as the requirements of the objective to which the content was related.

The results obtained from the tests were interpreted regarding to the type of test, as follows: for the minimum criteria of achievements for each category of knowledge it was taken $60.01 \%$ of the solved tasks. It means that if the students in the appropriate category have solved a minimum of $60.1 \%$ of the tasks related to the corresponding objective given in the Mathematics Curriculum, it can be claimed that they are able to accomplish that objective in that category. The achievement of objectives was determined based on the fulfillment of the minimum criteria in the category of knowledge determined by the classification of objectives given in the Mathematics Curriculum (Table 1).

The evaluation was related to the level of achievement of objectives of teaching about natural numbers for the third and fourth grade in Primary school. The highest number of objectives within a single class allows for quick, immediate evaluation. However, in our case the evaluation is done at the end of the school year, and such evaluation is indirect, and for each objective, higher levels of knowledge of quality can be achieved than those contained in it. Namely, the knowledge acquired at the beginning of the school year (at the beginning of the cycle) at one level will be higher in the end, because they are integrated into the knowledge system that follows.

\section{RESULTS OF RESEARCH AND DISCUSSION}

In order to determine the achievement of the requirements of the objectives, the level of realization of the same ones related to the contents about the natural numbers in the third and fourth grades in relation to the categories of knowledge of the taxonomic model was examined. According to the hierarchical order of knowledge categories, expectations were that students would achieve the best results in the category of recognition, and that the percentage of tasks solved would be reduced with the increase in the categories of knowledge of the taxonomic model. This is significant from the aspect of identifying the objectives that the students have achieved and determining the validity of the tasks given in the tests, and hence the taxonomic model itself.

\subsection{The achievement of objectives in the third grade}

The results obtained by examining the level of achievement of objectives of natural numbers in the third grade are given in Table 2.

Table 2 Percentage of objectives solvency in the third grade in relation to the categories of knowledge of the taxonomic model

\begin{tabular}{lccccccc}
\hline \multirow{2}{*}{ Knowledge category } & \multicolumn{7}{c}{ Percentage of task solution in relation to objectives requirements } \\
\cline { 2 - 8 } & 3.1. & 3.2. & 3.3. & 3.4. & 3.5. & 3.6. & 3.7. \\
\hline Recognition & 86.36 & 67.50 & 69.31 & 43.89 & 62.06 & 69.26 & 80.76 \\
Reproduction & 89.56 & 81.05 & 61.82 & 42.60 & 61.64 & 63.83 & 64.51 \\
Comprenhesion & 78.50 & 43.62 & 55.78 & 52.05 & 59.76 & 64.37 & 51.75 \\
Operationalization & 60.91 & 76.39 & 52.58 & 53.29 & 38.08 & 45.86 & 35.22 \\
Creative problem solving & 48.39 & 58.66 & 25.86 & 20.23 & 32.58 & 31.75 & 19.03 \\
\hline
\end{tabular}


If in Table 2 we observe the percentage of solution of objectives (columns), we see that the expected results were obtained in the case of objectives 3.3, 3.5. and 3.7. regarding that the students have achieved the best results in the recognition category by solving tasks related to these objectives (they solved $69.31 \%$ of given tasks in the case of objective $3.3,62 \%$ in the case of objective 3.5 and $80.76 \%$ in the case of a objective 3.7 ), while the percentage of task solvency decreases with the increase in the category of the taxonomic model.

The solved tasks that measure the level of accomplishment of the first and sixth objectives, the students achieved approximately the same results in the categories of recognition, reproduction and comprehension, while the percentage of the solved tasks in the following categories is decreasing (in the case of objective 3.1, they solved $60.91 \%$, or $48.91 \%$ of given objective, in the case of objective $3.6,45.86 \%$, or $31.75 \%$ in that order). Since the percentage of task solvency in the first objective is higher in the category of reproduction than the category of recognition, the $t$-value, of the difference between the percentages in solving problems between these two categories, is calculated, $t=-1,262$ and indicates the absence of a statistically significant difference.

In the case of the sixth objective, the obtained $t$ values between the first three categories of knowledge are: $\mathrm{t}=1,478, \mathrm{t}=0,334$ it $=-0,144$ in that order, which also does not indicate the existence of a statistically significant difference, so we can claim that in the case of these two objective obtained results are expected.

By solving the tasks related to the second objective, the expected results were not obtained because the students in the category of recognition and comprehension achieved lower results (they $67.5 \%$ in the first and $43.62 \%$ in the second category) compared to other categories $81.05 \%$ in the category of reproduction, $76.39 \%$ in the category of operationalization and $58.6 \%$ in the category of creative problem solving). Therefore, a notable analysis of the tasks formulated in the tests and results is done, and showed that the students: they do not know the ways of graphic numbering and the corresponding calculation operations, and do not understand the procedures on which the calculation operations are based, i.e. they know how to calculate the sum, the difference, the product and the quotient of numbers, but do not understand the procedures for reaching the solution, that is, they do not know why the calculations are carried out in an appropriate manner. In the case of the fourth thematic task, the students in the category of recognition and reproduction achieved lower results (they solved $43.89 \%$ in the first and $42.60 \%$ in the second category) compared to comprehension and operationalization (they solved $52.05 \%$ of tasks in the first, $53.29 \%$ in the second category). The comparative analysis of tasks and results obtained in the recognition and reproduction tests in relation to the same in the tests of comprehensive and operationalization has shown that students: are able to apply rules relating to the dependence and continuity of the sum, the difference, the product, and the quotient, depending on the change of their components, but they do not know to name the rule they used, and to verbalize it. If in Table 2 we observe the percentage of solvency of tasks related to the categories of knowledge of the taxonomic model (rows), we see that students in the category of recognition and reproduction achieved everything except objective 3.4 (thy solved $43.89 \%$ or $42.60 \%$ of the given task). With regard to the classification of objectives in the third grade (Table 1), it is specified that the students for the objective 3.4 achieve only the reproduction level which is not confirmed on the basis of the obtained results.

In the comprehension category, the students solved the first and the sixth objective. In case of objective 3.5 . the students solved $59.76 \%$ of given asks, which is $0.24 \%$ less than expected, therefore, additional analysis of the obtained results was made concerning the 
calculation of the percentage of students who achieved the set minimum criteria for this objective.

329 students did the test, 205 or $62.3 \%$ of them solved more than $60 \%$ of the given tasks, so we can claim that this objective was achieved. Considering that in this category it is expected for students to accomplish the objectives 3.5 and 3.6. we can say that expectations have been achieved in this category.

In the operationalization category, the students achieved only the first and second objectives where they solved $60.91 \%$ and $76.39 \%$ of the given tasks. Considering to the classification of objectives, students in this category should achieve four objectives (3.1, 3.2, 3.3 and 3.7). On the basis of the obtained results, we see that they achieved two, i.e. by solving tasks related to the first and second objectives, while they didn't achieve the set criteria by solving the tasks related to 3.3. and 3.7.

In the problem solving category, for no objective, students did not solve more than $60 \%$ of given tasks. In addition, the tasks related to the first and second thematic tasks were best solved, while in all other cases, the results were significantly lower.

If we compare the obtained results with the categories of knowledge for the objectives in the third grade that is expected for students to achieve, we see that the students achieved expectations in four objectives, i.e. by solving tasks related to objective $3.1,3.2,3.5$ and 3.6.

\subsection{The achievement of objectives in the fourth grade}

The level of achievement of objectives regarding to knowledge categories in the fourth grade is given in Table 3

Table 3 Percentage of objectives solvency in the fourth grade in relation to the categories of knowledge of the taxonomic model

\begin{tabular}{lccccccccc}
\hline \multirow{2}{*}{ Knowledge category } & \multicolumn{7}{c}{ Percentage of task solution in relation to objectives requirements } \\
\cline { 2 - 10 } & 4.1. & 4.2. & 4.3. & 4.4. & 4.5. & 4.6. & 4.7. & 4.8. & 4.9. \\
\hline Recognition & 88.15 & 88.23 & 82.58 & 80.18 & 62.22 & 73.76 & 65.65 & 81.73 & 83.23 \\
Reproduction & 88.17 & 84.63 & 82.85 & 63.70 & 62.26 & 59.43 & 68.39 & 61.16 & 69.21 \\
Comprenhesion & 57.97 & 81.89 & 60.47 & 69.35 & 48.46 & 62.64 & 50.50 & 63.54 & 52.08 \\
Operationalization & 59.00 & 51.56 & 58.02 & 65.51 & 55.61 & 48.83 & 39.22 & 44.34 & 27.16 \\
Creative problem solving & 34.04 & 82.94 & 34.26 & 71.50 & 34.68 & 18.77 & 25.82 & 36.62 & 30.37 \\
\hline
\end{tabular}

If in Table 3 we observe the level of achievement of objectives (columns), we see that in the fourth grade in six objectives the results point to minor deviations from the expected:

- By solving tasks of the first objective there are deviations relate to the solving of tasks in the recognition and reproduction and comprehension and operationalization categories where the percentage of tasks are done is approximately the same. Based on the calculated $t$-value of the difference, $t=-0.007$ in the first and $t=-0.253$ in the second case, we see that the difference obtained is not statistically significant, so we can talk about the expected results obtained since these are the close categories of knowledge.

- In the case of the objective 4.3 and 4.7.the deviations from expected ones refer to the results obtained in the categories of recognition and reproduction. The received values $=-0.089$, or $\mathrm{t}=-0.724$, indicate to the expected results. 
- In the case of objective 4.6.and 4.8 the deviations from expected ones refer to results obtained in the categories of reproduction and comprehension. The received values $t$ $=-0.812$, or $\mathrm{t}=-0.606$, indicate to the expected results.

- In the case of objective 4.9.the received t-value is different in the percentage of solution of tasks between the operationalization and creative problem solving categories and it is $\mathrm{t}=-0.855$ which also indicates that the expected results are obtained.

Based on the received results, we see that the students by solving the tasks related to the second objective, even in four categories they solved more than $80 \%$ of the given tasks. In the operationalization category, they achieved lower results compared to others.

By solving tasks related to the fourth objective, students achieved approximately equal results in all categories of knowledge, with a high level of solution. Therefore, expectations were not achieved, but students achieved significantly better results than expected, as they achieved all levels of knowledge determined by the taxonomic model.

In the case of the fifth objective, students achieved lower results in the category of comprehension compared to the results obtained by solving the tasks in the first two and the operationalization category. The analysis of the results obtained by solving the tasks of this category indicates that the students achieved lower results by solving the tasks related to reading and writing using the letters of the basic patterns of operations, where they should, the expressed verbally patterns of operations, interpret into the form of mathematical symbolism, i.e. to write them by using the letters, which had the effect of not achieving the expected results.

On the other hand, if in Table 3 we observe the percentage of solution of tasks related to the categories of knowledge of the taxonomic model (rows), we see that students in the category recognition achieved all objectives since they, by solving tasks related to this category, achieved the minimum criteria for assessing their fulfillment.

In the reproduction category, the students achieved all except the objective 4.6, (they solved $59.43 \%$ of the given tasks), while in the case of other objectives, they solved more than $60 \%$. If we compare the obtained results to the requirements given in the curriculum, we see that expectations were achieved since in this category it is expected that the students accomplish the objective 4.2 where the obtained results are shown as well.

In the comprehension category, students achieved the objectives 4.2., 4.3., 4.4., 4.6. and 4.8. Since that the curriculum expects the achievement of the objectives 4.3.and 4.4 we can say that the expectations are achieved in this category.

Based on the classification of objectives in the operationalization category, six objectives are expected to be achieved (4.1, 4.5, 4.6, 4.7, 4.8 and 4.9). By solving the tasks related to these objectives, less than $60 \%$ of the given tasks have been solved, so we cannot claim that they have achieved the same tasks. The only objective for which students in this category have met the minimum criteria is 4.4.

In the creative problem solving category, the students achieved outstanding results by solving the tasks related to the second and fourth objectives, where the total number of them was $82.94 \%$, i.e. $71.50 \%$, while in the cases of other objectives they achieved the expected results, concerning that it is the highest category of a taxonomic model and that the curriculum doesn't expect that students will achieve this level of knowledge for any objective.

If we compare the obtained results to identified knowledge categories of the objectives in the fourth grade obtained by analysis of the Primary Mathematics Curriculum, (Table 1), and in accordance with the set minimum criteria for achievement, we see that students achieved expectations in only three objectives, by solving tasks related to objectives $4.2,4.3$ and 4.4. 


\section{CONCLUSIONS}

Based on the obtained results, we can conclude that the students in the third grade achieved the requirements of the objectives related to: reading, writing and comparing natural numbers to 1000 and performed successfully all four calculation operations up to 1000 and to the level of operationally, calculated the values numerical expression with a maximum of three operations, determined the value of the expression with letters from the given letter value and solving equations and inequalities in a set of numbers up to 1000 to the category of comprehension, in accordance with the requirements related to these objectives in the Mathematics Curriculum of Primary Education. In all other cases, requests have not been achieved.

The obtained results also show that students do not know the ways of graphic numbering and corresponding calculation operations and do not understand the procedures on which calculation operations are based, i.e. they know how to calculate the sum, the difference, the product and the quotient of numbers, but they do not understand the procedures for determining the solution, they do not know why the calculations are carried out in an appropriate manner. This is a devastating fact, that in the way of achieving the objectives in the third grade in the curriculum it is stated that: "Only by understanding what a calculating operation in the actual tasks presents, in other words conscious decision making, and not speculation, when the certain operation should be applied, turns the calculation technique into real, and not formal knowledge" (The Curriculum for Third Grade of Primary Education, 2005, 2006, 2008 and 2010) In the fourth grade students achieved the requirements which are related to: knowledge of a set of natural numbers; integrating natural numbers of points of a number half-length and understanding the application of operations in the set $N$ or $N_{0}$. In all other cases, they did not achieve the level of knowledge that implied each of the objectives. Also, it is interesting that the Curriculum does not have a objective in the fourth grade that relates to the successful execution of calculating operations in the set $N$ and $N_{0}$, although they are acquired by content of program, and the method of realization of the program explains the procedures for their execution, which is a consequence of the non-alignment of objectives, outcomes and content, so that these requirements are not included by the survey.

On the other hand, only the objective related to reading and writing natural numbers in a decadal number system, all other objectives that are not achieved in basic, comprise the performing calculating operations in the set $N$, so the question arises: Is the cause of the failure of these objectives lies in the fact that the students did not master the calculating operations in the set $N$ ?

Since the students by solving the tasks which are related to the knowledge of a set of natural numbers and understand the application of operations in the set $N$ or $N_{0}$, achieved all levels of knowledge, they need to be reformulated in the Curriculum because they presume the level of reproduction or understanding.

Also, the obtained results indicate that in the initial mathematics teaching does not insist on correct use of the mathematical language since students: can apply the components of calculating operations, but they do not know how to name and verbalize it, and that they, verbally expressed components of operations, do not know how to translate into the form of mathematical symbolism, or to write them using letters. The curriculum states that: "The presence of algebraic propaedeutic in the program allows that in a deeper and higher level study the predetermined mathematical contents. In other words, using mathematical elements, students acquire knowledge with a higher degree of 
generalization" (The Curriculum for Fourth Grade of Primary Education, 2006, 2008) the results obtained in this way are consequence of the fact that teachers are not aware of the importance of the role of speech or proper mathematical expression in the formation of mathematical concepts and statements. In fact, the mathematical structures are constructed also under the influence of speech because "verbal expression stimulates the development of thinking and allows the external (physical) action to be transformed into an internal (thoughtmathematical) action" (Malinović-Jovanović, Malinović, 2013, 53) and in accordance with the degree of development of cognitive structures of children of this age.

The obtained results and the classification of program assignments given in the mathematics curriculum according to the given taxonomic model, and most of the requirements given in the curriculum do not correspond to the quality of knowledge that the students achieved on the tests. What is confirmed is that in all objectives related to content about natural numbers, students can achieve knowledge at the level of reproduction, which suggests that teaching is more focused on memory of facts than on their understanding and application.

Therefore, regardless of the curriculum based on operational objectives that enable adequate planning of teaching processes and procedures, they are more often realized in the categories of recognition and reproduction, and less in the categories of comprehension, application and problem solving. The reason of this is the fact that teaching is still performed in a traditional way and that the goal of the teaching units is not clearly set up according to the levels of knowledge which should be measured. Consequently, the student is not in a position to show that he has achieved the goal.

Also, based on the identified categories of knowledge for each of the objectives, the obtained results indicate which knowledge and level of quality are missing for our students for each objective related to content about natural numbers. Based on this, it can be determined by what types of learning and tasks can improve their knowledge, so that the obtained results can serve as guidelines for the directions in which changes in the organization of teaching should be made.

The similar results are being obtained from cycle to cycle and TIMSS research shows that the students from Serbia have the highest results obtained in the category of knowledge of facts, then in the category of comprehension of facts, and the weakest ones for reasoning, in other words in the category of creative problem solving, for which are considered to have been obtained as a consequence of the deficiency of our curriculum of mathematics which "does not determine the precise scope and depth of program contents and does not provide the basis for objectively assessing student performance, as well as successful individualization of teaching, so the directions in which they need to be changed are reflected in accepting access to science and mathematics education so that knowledge is hierarchically connected" (Milanović-Nahod, 2005, 350). Also, it was concluded that our students are weaker in solving tasks in which logical requirements are more complex. The results are better in knowledge and memory of facts, weaker in understanding the essence of concepts and relations, and the weakest in analyzing various situations and the practical application of knowledge, which is the consequence of the fact that in the teaching "less attention is paid to more complex mental operations, the most attention is on procedural aim which allows students to master the tasks well by solving the tasks concepts, so the lesser results of student achievement could be assumed when it comes to examining the presence of more complex cognitive abilities and skills "(Antonijević \& Veljković, 2005, 104). 
The results of this theoretical-empirical research can contribute to changes in the approach to teaching contents: in changing and innovating the mathematics curriculum, in presenting the content of the program; the operationalization of the goal and teaching tasks; the quality of evaluating and assessing student achievement; validity and quality of tests of knowledge and skills, and others.

\section{REFERENCES}

Anderson, L.W. (Ed.), Krathwohl, D.R. (Ed.), Airasian, P.W., Cruikshank, K.A., Mayer, R.E., Pintrich, P.R., Raths, J., \& Wittrock, M.C. (2001). A taxonomy for learning, teaching, and assessing: A revision of Bloom's Taxonomy of Educational Objectives (Complete edition). New York: Longman.

Antonijević, R., Veljković, M. (2005). Nastavni sadržaji i postignuće učenika iz matematike [Teaching Content and Achievement of Students in Mathematics]. U Antonijević R., Janjetović D. (prir.), TIMSS $2003 u$ Srbiji: Rezultati međunarodnog istraživanja postignuća učenika osnovne škole iz matematike i prirodnih nauka [TIMSS 2003 in Serbia: Results of International Research on the Achievements of Primary School Students in Mathematics and Natural Sciences] (str.81-107). Beograd: Institut za pedagoška istraživanja,

Bloom, B., Englehart, M., Furst, E., Hill, W. \& Krathwoll, D. (1956): Taxonomy of educational objectives: The classification of educational goals, Handbook I: Cognitive domain, New York, Toronto: Longman, Green and Co.

Blum, B. S. (1981). Taksonomija ili klasifikacija obrazovnih i odgojnih ciljeva - Knjiga I: kognitivno područje [Taxonomy of educational objectives: The classification of educational goals, Handbook I: Cognitive domain], Beograd: Republički zavod za unapređivanje vaspitanja i obrazovanja.

Bogdanović, S., Malinović-Jovanović, N.(2009). Taksonomski model i stepen ostvarenosti zadataka nastave matematike u III razredu osnovne škole [Taxonomic Model and Level of Achievement of Objectives in Teaching Math in Third Grade of Primary School]. Pedagogija [Pedagogy], 64 (4), Beograd, 618-632.

Bognar, L., Matijević, M. (2002). Didaktika [Didactic]. Zagreb: Školska knjiga.

Gagné, R., Briggs, L.\& Wager, W. (1992). Principles of Instructional Design (4th Ed.). Fort Worth, TX: HBJ College Publishers.

Krathwohl, D. R. (2002). A Revision of Bloom's Taxonomy: An Overview. Theory Into Practice, 41 (4), 212-218.

Mager, R. F. (1997). Preparing Instructional Objectives: A Critical Tool in the Development of Effective Instruction (3rd ed.). Atlanta, GA: The Center for Effective Performance.

Malinović-Jovanović, N. (2005). Savremeni program za savremene tokove u obrazovanju za mlađe razrede osnovne škole [The Contemporary Program for Contemporary Trends in Education in the Lower Grades of Primary School. U Savremeni tokovi u obrazovanju nastavnika [Contemporary Trends in Teacher Education] (str. 381-405). Vranje: Učiteljski fakultet u Vranju.

Malinović-Jovanović, N. (2010). Taksonomski model u funkciji inoviranja nastavnog programa matematike u osnovnoj školi [Taxonomic Model in the Function of Innovating Mathematics Curriculum in Primary School], Godišnjak Učiteljskog fakulteta [Annual of Teacher Training Faculty in Vranje], (1), Vranje, 193-220.

Malinović-Jovanović, N., Malinović, T. (2013). Metodika osavremenjene nastave matematike [Methodic of Contemporary Mathematics Teaching]. Vranje: Učiteljski fakultet.

Malinović-Jovanović N., Stojanović S. (2015). Operacionalizacija programskih zadataka i ishoda početne nastave matematike [Operationalization of objectives and outcomes of initial mathematics education]. U Marinković S. (ur.), Naučni skup:Nastava i učenje - evaluacija vaspitno-obrazovnog rada [Scientific Meeting: Teaching and Learning - Evaluation of Education], (str. 357-372). Užice: Učiteljski fakultet.

Marzano, R. J., Kendall, J. S. (2007). The New Taxonomy of Educational Objectives (2nd.Ed.). Heatherton, Vic.: Hawker Brownlow Education.VB

Milanović-Nahod, S. (2005). Znanje učenika od očekivanog do ostvarenog [Knowledge of Students from the Expected to the Achieved]. U Antonijević R., Janjetović D. (prir.), TIMSS 2003 u Srbiji: Rezultati međunarodnog istraživanja postignuća učenika osnovne škole iz matematike i prirodnih nauka [TIMSS 2003 in Serbia: Results of International Research on the Achievements of Primary School Students in Mathematics and Natural Sciences] (str. 327-350). Beograd: Institut za pedagoška istraživanja,.

Mullis, I. V. S., Martin, M. O., Graham, J. R., O'Sullivan, C. Y., Arora, A. \& Eberber, E. (2007). TIMSS 2007 Assessment Frameworks. Chestnut Hill, MA: Boston College.

Nastavni program za treći razred osnovnog obrazovanja $i$ vaspitanja [The Curriculum for Third Grade of Primary Education]. Službeni glasnik Republike Srbije - Prosvetni glasnik, br. 1, 2005, br. 15, 2006, br. 2, 2008, br.2, 2010. 
Nastavni program za četvrti razred osnovnog obrazovanja $i$ vaspitanja [The Curriculum for Fourth Grade of Primary Education]. Službeni glasnik Republike Srbije - Prosvetni glasnik, br. 3, 2006, br. 15, 2006, br.2, 2008.

Pravilnik o ocenjivanju učenika u osnovnom obrazovanju $i$ vaspitanju [The Regulations of the Assessment of Students in Primary Education]. Službeni glasnik RS, br. 72, 2009, br. 52, 2011, br. 55, 2013.

Pravilnik o obrazovnim standardima za kraj prvog ciklusa obaveznog obrazovanja za predmete srpski jezik, matematike i priroda i društvo [The Regulation of the Educational Standards for the End of the First Cycle of the Compulsory Education for School Subjects Serbian Language, Mathematics and Nature and Society]. Službeni glasnik RS - Prosvetni glasnik, br. 5, 2011.

The Glossary of Education Reform. (2014). Portland ME: Great Schools Partnership. Retrieved November 13 , 2017, from the World Wide Web: http://edglossary.org/blooms-taxonomy/

Tyler, R. (1949). Basic principles of curriculum and instruction. Chicago: The University of Chicago Press.

Vučić, L. (1979). Kriterijski testovi - nov prilaz testiranju znanja [Criterion-Referenced tests - a New Approach to Testing Knowledge], Psihologjia [Psychology], 12 (3-4), 26-35.

\section{POSTIGNUĆA UČENIKA I ZAHTEVI PROGRAMSKIH ZADATAKA U NASTAVNOM PROGRAMU MATEMATIKE ZA OSNOVNU ŠKOLU}

U radu su prikazani rezultati istraživanja postignuća učenika III i IV razreda osnovne škole u odnosu na zahteve programskih zadataka i ishoda datih u Nastavnom programu matematike za osnovnu školu. Za ispitivanje postignuća učenika, odnosno stepena ostvarenosti programskih zadataka nastave o prirodnom brojevima korišćen je taksonomski model operacionalizacije cilja $i$ zadataka nastave matematike. Istraživanje je sprovedeno na uzorku od 341-og učenika III i 315 učenika IV razreda tri osnovne škole u populaciji učenika III i IV razreda osnovnih škola Pčinjskog okruga u Srbiji. Korišćena je deskriptivna metoda u svim njenim varijantama: analitickoj, komparativnoj i klasifikacionoj, a u skladu sa tim primenjivana je tehnika analize sadržaja i testiranje. Kao instrument, korišćeni su kriterijski testovi, s obzirom na to da se njima utvrđuje šta i do kog nivoa znanja po kvalitetu su učenici savladali od onoga što je planirano. Rezultati dobijeni istraživanjem ukazuju na to da učenici nisu postigli većinu programskih zadataka datih u Nastavnom programu, s obzirom na kvalitet znanja koji podrazumevaju, a koji je utvrđivan na osnovu izvršene analize zahteva programskih zadataka $i$ ishoda $u$ odnosu na kategorije znanja taksonomskog modela. Doprinos istraživanja ogleda se u promenama $u$ pristupu sadržajima nastave $i$ to: u menjanju i inoviranju nastavnog programa matematike; načinu prezentovanja sadržaja programa; operacionalizaciji cilja i zadataka nastave; kvaliteta vrednovanja $i$ ocenjivanja postignuća učenika; validnosti i kvaliteta testova znanja i sposobnosti i dr.

Ključne reči: programski zadaci, taksonomija, postignuća učenika, stepen ostvarenosti programskih zadataka nastave, nastavni program matematike 